RESEARCH PAPER

\title{
The Virginia Slims identity crisis: an inside look at tobacco industry marketing to women
}

\section{B A Toll, P M Ling}

See end of article for authors' affiliations

\section{Correspondence to:}

Benjamin A Toll, PhD, Yale University School of Medicine, Department of Psychiatry, 1 Long Wharf, Box 18, New Haven, CT 06511, USA:

benjamin.toll@yále.edu

Received 9 June 2004 Accepted 10 January 2005

\begin{abstract}
Objectives: Because no prior studies have comprehensively analysed previously secret tobacco industry documents describing marketing female brands, the Virginia Slims brand was studied to explore how Philip Morris and competitors develop and adapt promotional campaigns targeting women.

Methods: Analysis of previously secret tobacco industry documents. The majority of the documents used were from Philip Morris.

Results: The key to Virginia Slims advertising was creating an aspirational image which women associated with the brand. Virginia Slims co-opted women's liberation slogans to build a modern female image from 1968 through to the 1980 s, and its market share grew from $0.24 \%$ to $3.16 \%$ during that time period. Ironically, the feminist image that worked very well for the brand was also the reason for its subsequent problems. Philip Morris experienced unprecedented losses in market share in the early 1990s, with a decline in market share for four consecutive years from $3.16 \%$ to $2.26 \%$; they attributed this decline to both the fact that the brand's feminist image no longer appealed to young women aged 18-24 years, and increased competition from more contemporary and lower priced competitors. Throughout the 1990s, attempts to reacquire young women while retaining Virginia Slims loyal (now older) smokers were made using a "King Size" line extension, new slogans, and loyalty building promotions.

Conclusions: Tobacco advertisers initially created distinct female brands with aspirational images; continued appeal to young women was critical for long term growth. The need for established brands to evolve to maintain relevance to young women creates an opportunity for tobacco counter-marketing, which should undermine tobacco brand imagery and promote aspirational smoke-free lifestyle images. Young women age 18-24 are extremely valuable to the tobacco industry and should be a focus for tobacco control programmes.
\end{abstract}

A ccording to the Centers for Disease Control and Prevention, smoking causes approximately 178000 premature deaths among women annually in the USA. ${ }^{1}$ In 1965, the absolute smoking prevalence among women was $18 \%$ below men; in 1993 that difference narrowed to $5 \%$ and has remained at $5 \%$ as of $2002 .{ }^{2}$ The 2001 US Surgeon General's report on women and smoking documented aggressive tobacco marketing targeting females, and concluded that tobacco marketing is a factor influencing susceptibility to and initiation of smoking among girls. ${ }^{3}$

While tobacco industry marketing to women has been recognised, prior studies do not provide insight into the internal processes of the tobacco industry while researching, designing, testing, executing, and monitoring the success of marketing campaigns. A 1998 settlement from the Minnesota state litigation against the tobacco industry and the subsequent 1998 Master Settlement Agreement resulted in the release of millions of pages of previously secret tobacco industry documents, which provide an opportunity to analyse tobacco marketing campaigns targeting women from "inside" the industry. Such analyses may reveal how the industry accomplishes its goals, what elements tobacco companies view as critical to successful campaigns, and the industry's self identified weaknesses and failures.

We analysed tobacco industry documents regarding Virginia Slims, the first and most successful brand marketed exclusively to women in the USA. As of 2004, this brand continued to be one of Philip Morris (PM) USA's four "focus brands" (along with Marlboro, Parliament, and Basic), and it is also marketed internationally. ${ }^{4}$ While there is an extensive literature on the importance of Virginia Slims as the first successful "women's brand", ${ }^{56}$ this literature is based on an analysis of advertising campaigns along with assessments of their effects on smoking among women. To date, no one has provided an analysis of Virginia Slims from the perspective of the people developing and marketing the brand using the tobacco industry documents. We analysed internal tobacco industry documents to describe the strategic planning and marketing research that guided campaign development, and how PM honed strategies to market to women during the 35 year history of this brand.

Virginia Slims' early success was attributed primarily to its advertising campaign. Philip Morris's flagship "You've Come a Long Way, Baby" campaign resonated strongly with the values of young women during the 1970s and was utilised for multiple advertising campaigns. The strength of this campaign's connection to the feminist movement led to an identity crisis for the brand in the early 1990s. Philip Morris observed that the brand had lost relevance to young women, who no longer identified with the "brand personality" (that is, the aspirational image the brand conveyed) that had been built over the prior two decades. Virginia Slims also faced increased competition from new female brands with more contemporary images and lower prices. In response to this threat, PM conducted extensive market research focused on young females and smoking, and engaged in several efforts to regain market share, including developing Virginia Slims Kings, a line extension designed to appeal specifically to young females. Nonetheless, PM had difficulty using a single brand image to both retain loyal (aging) Virginia Slims smokers and attract new younger smokers. 


\section{METHODS}

We searched tobacco industry document archives from the University of California, San Francisco Legacy Tobacco Documents Library (legacy.library.ucsf.edu), and Tobacco Documents Online (www.tobaccodocuments.org). Tobacco industry documents internet sites (Philip Morris, www. pmdocs.com; RJ Reynolds, www.rjrtdocs.com; Lorillard, www.lorillarddocs.com; and Brown \& Williamson, www. bwdocs.com) were searched for supplemental information when documents could not be retrieved from the nonindustry sites. These documents were made public as a result of the 1998 settlement of the Minnesota state litigation against the tobacco industry and the ensuing 1998 Master Settlement Agreement.

Searches were conducted between June 2003 and May 2004. Initial search terms combined the brand name "Virginia Slims" with terms to identify research, such as "study," "research," "focus groups," or "qualitative," and terms to identify marketing strategies, such as "marketing report," "strategic," "plan," or "market share." Initial searches yielded thousands of documents (for example, the initial search for "Virginia Slims" yielded 191420 "hits"); those related to marketing Virginia Slims were selected. Searches were repeated and focused using standard techniques. ${ }^{7}$ Further "snowball" searches for contextual information on relevant documents were conducted using names, project titles, competing brand names (such as Capri and Misty), locations, dates, and reference (Bates) numbers. This analysis is based on a final collection of approximately 570 research reports, presentations, memorandums, advertisements, and plans, which were analysed in detail. The bulk of the retrieved documents are from Philip Morris Tobacco Company, the maker of Virginia Slims; we included documents from other tobacco companies when they addressed competition with Virginia Slims. We focused especially on internal strategic planning, brand plans, market share, and other marketing research that guided campaign development. Both authors independently reviewed the documents and wrote summary memoranda. Common themes were identified and discussed; differences were resolved primarily by gathering additional data (for example, if two conflicting documents were found, other documents were retrieved in an effort to find support for one of the two documents). Information found in industry documents was triangulated with data from searches of the published literature, tobacco company annual reports, online search engines (such as Google), and advertising archives available online (such as the Richard Pollay advertising collection (http://roswell.tobaccodocuments.org/pollay/dirdet.cfm) or www.trinketsandtrash.org).

\section{RESULTS}

\section{Virginia Slims: early history and overview of the brand}

A 1967 PM presentation on Virginia Slims notes that women had been an important part of the cigarette market since Lucky Strike's "Reach for a Lucky instead of a sweet" campaign in the 1920s, but despite several prior attempts, no cigarette made exclusively for women had yet found success. ${ }^{8}$ A 1969 PM memo states that before the 1960s, although the proportion of female smokers was growing, advertising had been aimed mainly at men with women constituting an incidental part of the campaign. ${ }^{9}$ The cigarette product that was marketed as Virginia Slims was inspired by American Tobacco Company's Silva Thins, the first thin cigarette on the market in 1967, which was not targeted to women. ${ }^{10-12}$ The Leo Burnett Agency, PM's primary advertising consultant, which was "working on the idea of a women's cigarette" for them, seized on the observation that "women saw a style feature to the slim length" to develop the Virginia Slims campaign. ${ }^{10}{ }^{13}$ A 1969 memo from Edward J Gray, director of marketing research for PM International, to Milton L Rusk, director of marketing for PM International, ${ }^{14}$ explains that Silva Thins and Virginia Slims were developed with a specific market segment in mind:

[T] he concept for a consumer segment did precede the development of the reduced diameter cigarette... research and creativity worked together for both Silva Thins and Virginia Slims. In both instances the usual process was reversed. Historically, the products were developed by the manufacturing people and then tested or then turned over to market to sell. In the case of the thin cigarettes, the concept of a market segment came first and then the development of the product. $^{9}$

Research conducted in late 1968 by PM's competitor, the American Tobacco Company, noted that "advertising was easily the most important reason offered by women smoking Virginia Slims" for trying the brand, ${ }^{11}$ a phenomenon that was also found in several PM studies. ${ }^{15} 16$

The Leo Burnett Agency developed the "You've come a long way, baby" campaign in 1968. This campaign utilised women's rights to highlight the difference between men and women in a "fun" way. ${ }^{13}$ Both Leo Burnett and PM regarded the "brand personality" as the key to Virginia Slims's success. Prior unsuccessful appeals to women had emphasised cosmetic, romantic, or only physical characteristics of the cigarette. ${ }^{10}$ Although female brands were introduced after Virginia Slims, such as Eve (1970) or Satin (1983), many did not establish a relatable brand personality; this was a critical difference according to a 1986 PM presentation that reflected on the development of Virginia Slims in the 1960s and 1970s:

What did the excellent creative do to this concept, was to offer something that EVE and SATIN never did - brand personality. A brand that was feminine but was nonthreatening. It was "user friendly." The women were women who could make choices but had not lost their femininity. The brand was aspirational... ${ }^{13}$

Philip Morris's early assessments of Virginia Slims's performance showed advertising recall, brand awareness, trial rate, and conversion rate were all "impressively high". Sales of Virginia Slims increased steadily since its introduction, and PM regarded achieving a market share of $1 \%$ nationally as a "smashing success" ${ }^{17}$ Over the next 20 years, Virginia Slims showed a steady growth in market share (fig l).

During the 1970s, Virginia Slims's success was also noted by PM's competitors. A 1979 RJ Reynolds review of the women's cigarette market and analysis of Virginia Slims's success notes women smokers grew from $45 \%$ to $48 \%$ of total smokers and their volume contribution to the cigarette market grew from $41 \%$ to $45 \%$ between 1970 and $1979 .{ }^{18}$ RJ Reynolds also found that awareness and recall of Virginia Slims was particularly strong among young women (age 1834 years) and was further supported by a consistent central advertising campaign idea, "You've come a long way, Baby", which had not changed since $1968 .^{18}$ In addition to cigarettes, branded non-tobacco items and sports sponsorship reinforced the brand image as early as $1970 .{ }^{18}$ RJ Reynolds found that premium branded items, such as the Book of Days engagement calendar, which was introduced in 1971, were "quality products at a reasonable price" that "evoked a good 


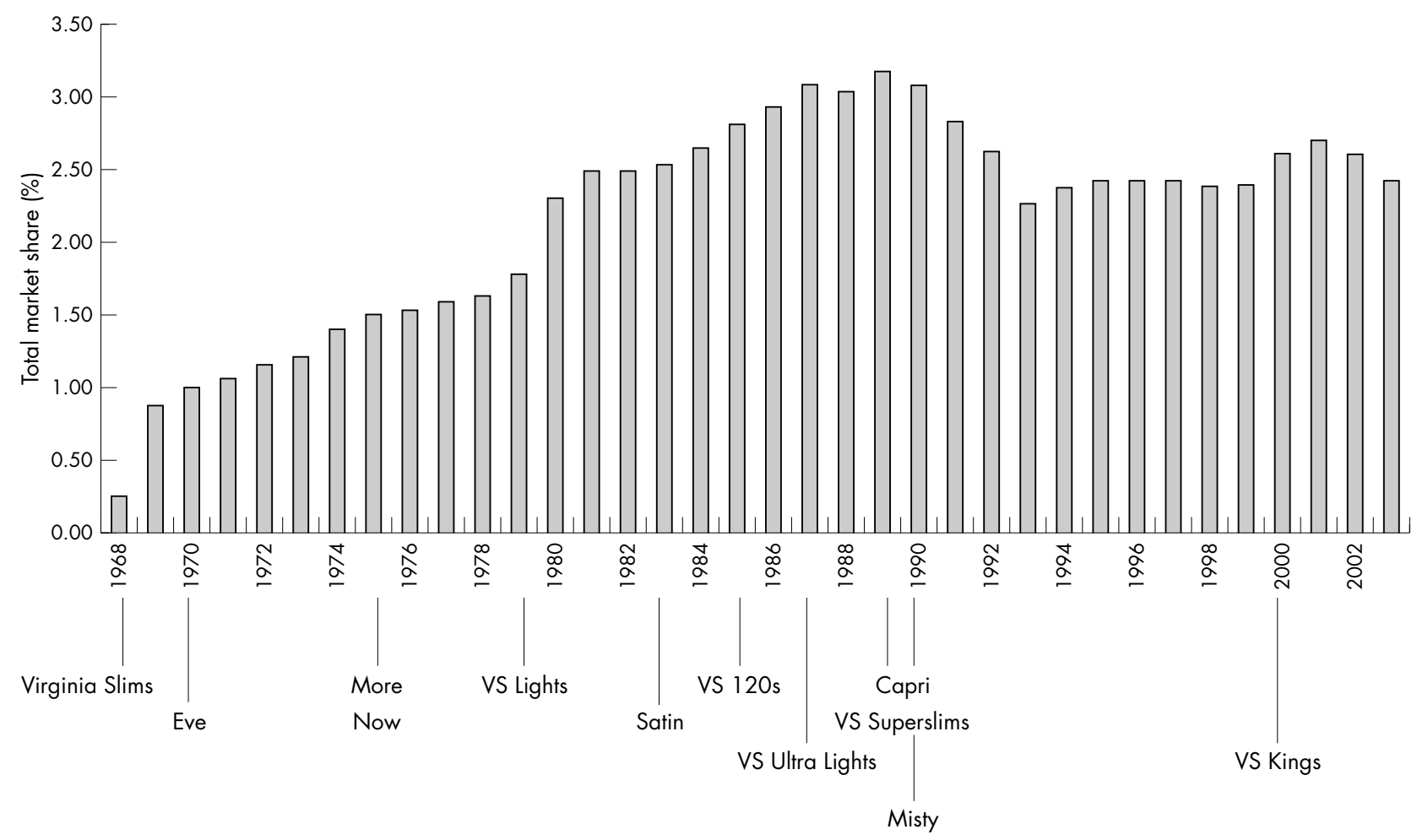

Major female brand introductions

Figure 1 Virginia Slims total market share from 1968 through 2003.4 26 $105-109$

feeling about the product from consumers" and "went along with the brand and its image". ${ }^{18}$ In 1976, Virginia Slims offered a tennis sweater and jersey in association with the brand's sponsorship of tennis tournaments. ${ }^{18}$

Line extensions were another source of market growth, especially during the $1980 \mathrm{~s} .{ }^{19}$ Virginia Slims's sales increased by $37.4 \%$ and market share grew from $1.6 \%$ to $2.2 \%$ in three months after the introduction of Virginia Slims Lights in 1979. ${ }^{20}$ Between 1979 and 1989, Virginia Slims brand share grew fairly steadily, bolstered by the introduction of line extensions such as Virginia Slims Ultra Lights and Virginia Slims Superslims. ${ }^{19}$ These line extensions were progressively slimmer, longer, and lower in tar and nicotine, which implied to consumers that they were healthier, addressing health concerns of many smokers. ${ }^{21-23}$ The 1989 Superslims line extension attempted to address both health and greater socially acceptability, advertising $70 \%$ less sidestream smoke. ${ }^{24} 25$ After 1990, additional line extensions did not appear to improve Virginia Slims overall market share (fig 2).

A 1989 Leo Burnett report recognised that between 1985 and 1988, Virginia Slims share among younger women (age 18-24 years) dropped from $11.1 \%$ to $9.3 \%$ with "Marlboro and Newport grabbing larger share of young market than in the early $80^{\prime} \mathrm{s}^{\prime \prime} .{ }^{19}$ In addition, the size of the female 18-24 year old population who smoked was decreasing; "only 13\% of female smokers are age 18-24 now, as opposed to almost 16\% in 1985". ${ }^{19}$ As fig 1 illustrates, between 1990 and 1993 Virginia Slims market share declined for the first time in the brand's history.

\section{The crisis and competition Virginia Slims faced in the early 1990s}

After experiencing gains in market share and growth for approximately 21 years, Virginia Slims started to show steady declines in market share beginning in $1990 .^{26}$ In the early 1990s new brands like Misty also began to compete with both feminine image and discount prices. ${ }^{26}$ This crisis for the brand elicited a strong response from PM and Leo Burnett. ${ }^{27}$ First, PM and Leo Burnett assessed "how image was communicated and perceived ${ }^{\prime 27}$ because the aspirational image was considered key to the brand's growth. The second critical issue PM identified was that this decline in market share was "led by severe erosion among YAFS [Young Adult Female Smokers], followed by softening among 25-34", and "YAFS were of particular importance given they represented [and] foreshadowed the brand's long-term performance". ${ }^{27}$

Philip Morris identified the Capri and Misty brands as two of Virginia Slims' major competitors. In 1993, of the competitive female brands, Capri spent the most on advertising media, ${ }^{28}$ and most women who switched brands from Virginia Slims switched to Misty. ${ }^{26}$ Brown \& Williamson Tobacco Company had introduced Capri nationally in $1988,{ }^{29}$ and many of the early Capri advertisements were very similar to Virginia Slims, featuring fashionable, glamorous women. ${ }^{30}$ In 1990, American Tobacco Company introduced the female brand Misty, with advertisements that evoked a young image:

- The MISTY SLIMS smoker is beleived [sic] to be a young, recreational/social smoker. However, Female Brand smokers thought any woman could smoke MISTY SLIMS. So while the image may be that of a younger woman, the Brand appeals to women of all ages.

- The "PUNK" campaign definitely projects MISTY SLIMS fashionability, trendiness and an image of a younger smoker. ${ }^{31}$

In addition, Misty was offered at discount prices. ${ }^{32}$ In 1994 Brown \& Williamson's parent company, British American 


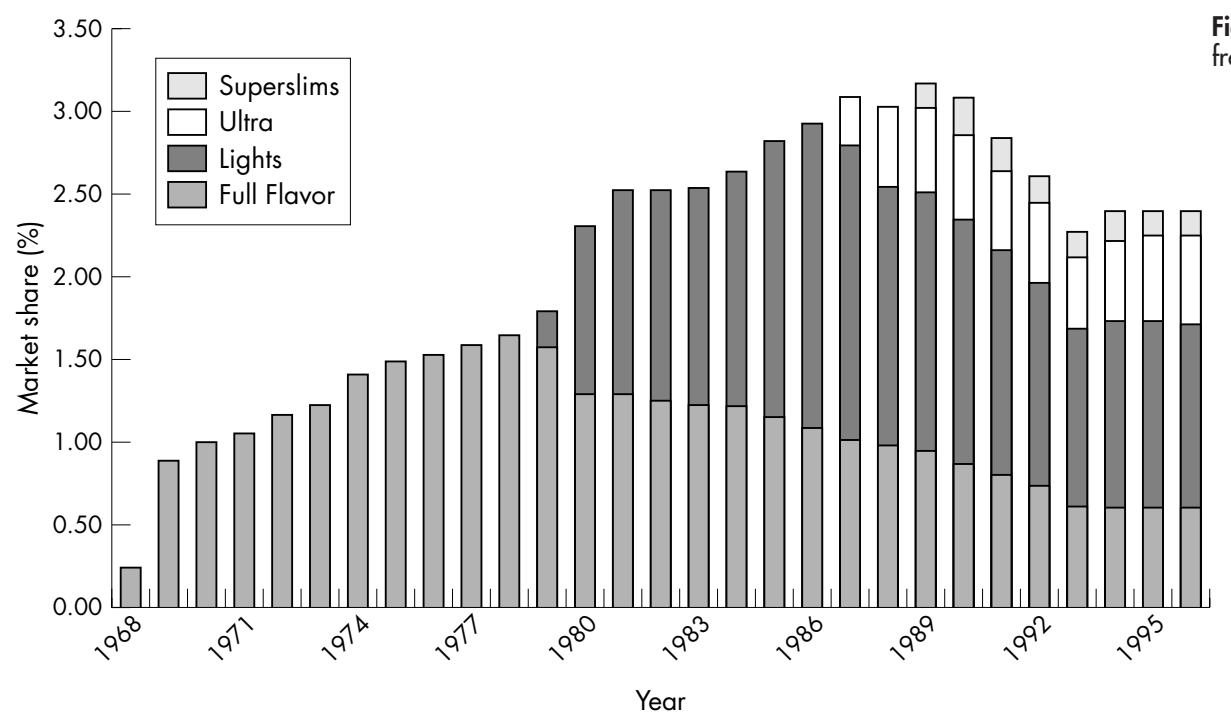

Figure 2 Virginia Slims line extensions from 1968 through 1996. ${ }^{26} 105$

Tobacco, purchased American Tobacco Company and took over management of its brands, including Misty. ${ }^{33}$ A 1995 Misty brand plan recognised that the image attributes of both Misty and Capri created an opportunity to "divide and conquer" Virginia Slims (fig 3).

\section{PM's response to the Virginia Slims identity crisis} Qualitative market research

In 1989 PM and Leo Burnett undertook a series of qualitative image studies to better understand the reasons for Virginia Slims's decline among young women. ${ }^{27}$ This underscores the central importance of the brand's aspirational image. PM needed to discover why the images that worked so well in the 1970 s and 1980s began to fail. It was particularly important to discover why young females were no longer responding positively to Virginia Slims marketing. We identified 11 studies devoted to this problem; the five studies discussed here illustrate important problems with which PM struggled.

Marketing Perceptions, Inc conducted a study in March 1991 entitled "Exploring attitudes, lifestyles and generational statements of young adult women". ${ }^{34}$ This study found that Virginia Slims's signature slogan "You've come a long way,
Baby" had little or no relevance to the women sampled. Among these women top priorities were:

- Money, material acquisitions, a good job (pays well, more so than gratifies)...

- Fears: Risks with commitment to relationships, marriage, children...

- Social activism, political statements: None. ${ }^{34}$

The formerly uniting theme of social activism now possessed no relevance for young female smokers, and in some circumstances was a turn off. Regarding respondents' views on women's rights, they found that "Virginia Slims 'rallying cry' [that is, the signature slogan] seems to have little relevance as a social statement or as an aspirational or 'acquired' image". ${ }^{34}$ Importantly, they often viewed the "Women's Movement" negatively, seeing it as "'something that happened in the $60^{\prime} \mathrm{s}$,' aggressive women protesting, burning bras, 'trying to open job opportunities"'. ${ }^{34}$ These women said that they could not picture themselves protesting anything, and they "were so narrowly focused to self and immediate circles of friends that they have no sense of

\section{RING-FENCE STRATEGY -DIVIDE-AND-CONQUER-}

Figure 3 Brand plan for Misty and Capri to "divide and conquer" Virginia Slims.

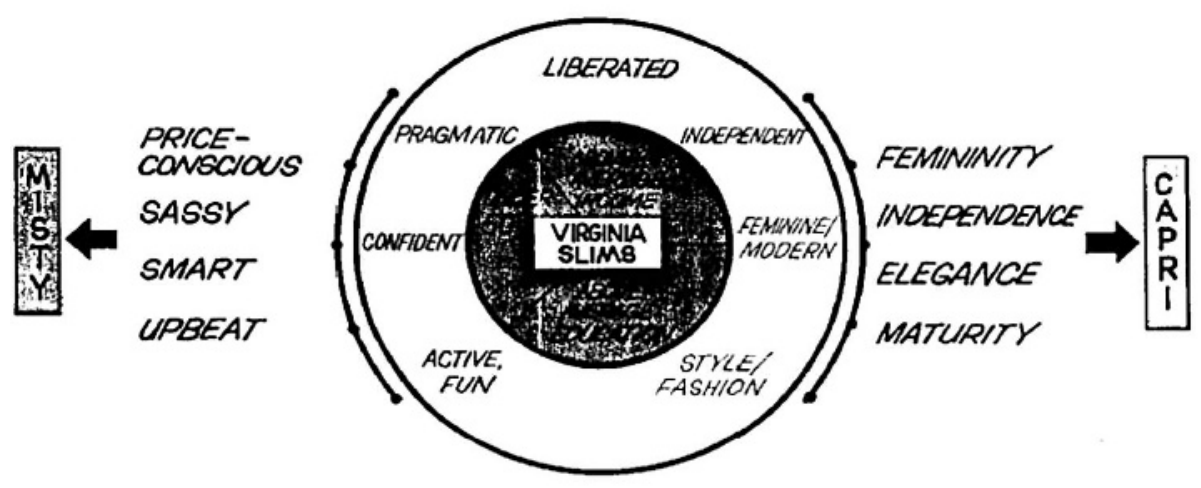


generation, generational style or statement". ${ }^{34}$ Apparently, the slogan and identity that had once worked well for Virginia Slims had lost its significance for young women.

In August 1993 and February 1994, studies were conducted to compare Virginia Slims to competitors Eve, Capri, and Misty and to assess Virginia Slims merchandise, like the "Book of Days" and "V-Wear", a direct mail catalogue of Virginia Slims clothing and accessories. ${ }^{35} 36$ Misty smokers indicated that they were initially attracted to the brand because of its discounted price, adding that despite the discounting, the brand still looked attractive and seemed feminine. ${ }^{37}$ The memos summarising the results of both studies tend to emphasise the positive findings for Virginia Slims. ${ }^{37}{ }^{38}$ For example, a 1994 memo from PM employee Yvette Rodriguez to Clark Murray, senior brand manager for Virginia Slims, ${ }^{39}$ states:

The new Virginia Slims' [sic] campaign generated a slightly older ( $\left.30^{\prime} s\right)$, more established and confident image for the brand. The previous campaign was perceived as younger $\left(20^{\prime} \mathrm{s}\right)$ and more carefree. Although the campaigns evoked different attitudes/image, both were perceived as appropriate for Virginia Slims. ${ }^{37}$

Since the goal of the studies was to assess the brand's ability to attract young female smokers, this finding of appeal to older women was potentially damaging, yet for reasons that are unclear, this finding was given a positive spin.

In January, 1994, a study was conducted to develop a new Virginia Slims "Quotes" campaign. ${ }^{40}$ Women were shown quotes which were viewed as "reflecting the modern, 90's women [sic]: strong; self sufficient; a woman who makes her own choices; a leader, rather than a follower" ${ }^{40}$ Rather than conveying a feminist theme, these quotes were seen as boosting self image and self esteem. These quotes were listed as promoting the new theme: "Honesty will get you everywhere; There is no alternative to being yourself; Be yourself... it's a tough act to follow; There are not shoes you can't fill". ${ }^{40}$ A PM memo describing this study concludes, "overall, the headlines presented were perceived to be positive, inspirational, and thought provoking. The quotes provide an updated and contemporary image for Virginia Slims while still being consistent with smokers' perceptions of the brand". ${ }^{41}$ This highlights one of the biggest problems for Virginia Slims: trying to keep their older, loyal smokers while attempting to make the brand relevant to new young smokers. Quotes similar to those tested in this research appear in Virginia Slims advertising in the 1990s.

A qualitative study from November 1994 showed how PM tried to discover what aspirational image would work best for Virginia Slims. ${ }^{42}$ In addition to interviews, women were shown "cigarette and general advertising" and asked to choose the ads that represented "Who I am", "Who I am not", and "Who I want to be". ${ }^{42}$ Several key themes emerged as important to women, including work/family choices, independence, women's roles and responsibilities, and friendships. Aspirational fashion looks included: elegant women, sophisticated professional women, casual but professional "looks", carefree attitudes and styles, and "looks" which were sensual though not overly "sexy". Women rejected fashion looks that were appropriate for "fashion show runways", "too different", or "'trampy looking' or 'too overtly sexual"'. ${ }^{42}$ During 1995 and 1996 Virginia Slims advertising dropped its longstanding "You've Come a Long Way, Baby" tag line, and substituted, "It's a Woman Thing." ${ }^{43-45}$ Very few substantive documents were located regarding the "It's a Woman Thing" campaign and the subsequent Virginia Slims campaign, "Find Your Voice".

\section{Introduction of Virginia Slims Kings}

One direct response to the erosion of young adult female smokers entering the Virginia Slims franchise was the creation of the line extension, Virginia Slims Kings. PM began conducting research on this new product, which had a shorter length and larger circumference than the traditional slim cigarette, as early as June $1991,{ }^{46}$ and found that the concept of Virginia Slims Kings was received positively: "[the] name still implies feminine...although not as feminine or upscale as 100 's more typical of the average female smoker". ${ }^{46}$ It appears that PM wanted to keep the Virginia Slims name and create a unique campaign relevant to young women.

In a qualitative study from December 1991, "as part of a long range effort to attract new consumers to the Virginia Slims (VS) brand", exploratory research was commissioned to explore reactions to cigarettes of different circumferences and length. ${ }^{47}$ The primary outcome of this study was that there was interest in the new product: "A respondent in an 'older' smokers group summed up the major finding for this study: 'Now there's a chance to have a woman's cigarette that's not prissy."'47 According to PM, ideally the new product:

...would allow the following to happen: Women would
have the option of a 'feminine' cigarette, in terms of taste
and image, but it would have the 'look' of a non-feminine
cigarette in public. The image of VS products as 'looking
prissy' and appealing to a certain kind of woman
[upscale, older, white collar, sophisticated, etc.] would
shift, and a new user might be created from the rank and
file of other brands [including Marlboro Light]. ${ }^{47}$
[bracketed comments in original]

This is exactly what Virginia Slims needed in the early 1990 's - a new image that would appeal to young females.

PM correspondence from Virginia Slims brand manager Carl Cohen to Suzanne LeVan, the vice president of marketing for premium brands, ${ }^{48}$ from 31 March 1993 discussed the development of Virginia Slims Kings. ${ }^{49}$ The segment being marketed to is explicitly stated, with a mention of a desire for discounted pricing: "The primary target audience is women smokers $18-24 \ldots$ Volume is likely to source from many brands, especially with the recommended discount pricing. Marlboro and Newport have the largest volume bases [among women 18-24], while discount brand [sic] show the most momentum." ${ }^{49}$ Some of the later documents discussing Virginia Slims Kings increase the age of the target audience. A 1995 presentation plans to reach out to "transitional 21 to 29 year old young adult women". ${ }^{50}$ In a PM memo from Alina Rothman to Mary Jo Gennaro dated 15 December 1999, a Virginia Slims Kings 2000 event objective is stated to "generate awareness and increase Virginia Slims appeal among competitive adult female smokers [that is, smokers of a brand other than Virginia Slims] 21-29 years of age $^{\prime \prime}{ }^{51}$ Two PM memos from Jody Begley to Connie Bulanda from January 2000 indicate they intend to reach "25-34 year old female smokers". ${ }^{52}{ }^{53}$ The reason for the shift to targeting 21-29 and 25-34 year olds instead of 18-24 year olds, as originally planned in the early 1990s, is not explicitly stated.

Although a product launch in the third quarter of 1993 was discussed in earlier documents, ${ }^{54}$ there are 1995 PM memos and documents regarding a Virginia Slims Kings launch in October $1996 .^{5055}$ It appears that the product launch was pushed back. In a document entitled "Virginia Slims Kickoff Meeting" from 17 November 1995 the erosion of young adult female smokers is presented in a chart that depicts the percentage of women broken down by age categories (fig 4), which shows that Virginia Slims is in the top five brands 


\section{Virginia Slims ranks among the top 5 brands among Figure 4 Reproduction of a Philip women smokers. However, it is \#5 among 18-24 year old Morris document showing that Virginia women.

\begin{tabular}{|c|c|c|c|c|c|c|c|}
\hline & $18-24$ & $25-29$ & 30-34 & $35-44$ & 45-54 & 55-64 & $65+$ \\
\hline 1) & Marlboro & Marlboro & Marlboro & Marlboro & Marlboro & Marlboro & Marlboro \\
\hline 2) & Newport & Newport & Newport & V. Slims & Winston & Salem & Salem \\
\hline 3) & Camel & V. Slims & V. Slims & Salem & Salem & Winston & Doral \\
\hline 4) & Basic & Doral & Salem & Doral & Doral & Doral & $\mathrm{B} \& \mathrm{H}$ \\
\hline 5) & V. Slims & Salem & Doral & Winston & V. Slims & V. Slims & Winston \\
\hline $\begin{array}{l}\% \text { of } \\
\text { Women } \\
\text { Smokers }\end{array}$ & $12.7 \%$ & $10.7 \%$ & $14.5 \%$ & $25.5 \%$ & $18.4 \%$ & $10.4 \%$ & $7.8 \%$ \\
\hline
\end{tabular}

among women, but it is fifth among 18-24 year olds. ${ }^{50}$ "Rejecters" of Virginia Slims viewed the image of the brand as being for age 35+, and the brand was still seen as representing "feminism". Apparently as late as 1995, Virginia Slims had failed to change its brand profile and image.

In a Marketing Perceptions, Inc qualitative study conducted in March 1996 the first key finding was:

\section{...herd smokers are likely to accept and even welcome a new or different image from Virginia Slims, given a product which looks different (king size) than the current product and which communicates a contemporary and relevant message. The current Virginia Slims product-a long, skinny cigarette that is perceived as 'for older women'-precludes it from being in these smokers' consideration set. $^{56}$}

The second key finding was that: "Of the new product concepts reviewed within these groups, a light king size product which offers good depth of flavour prompted the most appeal, while serving to deflect these smokers' perceptions that Virginia Slims is too light a cigarette for them" ${ }^{\prime 56}$ The third key finding was that the three concepts reviewed "contained elements which were relevant to some smokers within the sample and communicated a meaningful change from the current Virginia Slims imagery". ${ }^{56}$ This document illustrates that as late as 1996 Virginia Slims was still viewed as a cigarette for older women, and this is a concept that PM was eagerly trying to change.

We were unable to locate documents that discussed why Virginia Slims Kings was apparently not launched in 1996 as planned. In July 1998, a qualitative study further explored the concept of Virginia Slims Kings. Responses to the proposed campaigns were mixed, but certain consistencies were found:

Images which fit with a regular-size cigarette and were appealing/aspirational to female king-size smokers include: Strong and empowered women (confident; competent; in control); Bold women who speak their mind; Women viewed as individuals (comfortable with 'who ( $\mathrm{am}^{\prime}$ ). Female smokers appreciated images which celebrate women's strength, rather then images which were perceived as 'putting down men. ${ }^{157}$
In a PM memo discussing this research, specific campaigns that were viewed favourably were "the most successful in communicating images of 'female strength' and empowered women in control" ${ }^{58}$ Thus, in 1998, eight years after Virginia Slims's signature campaign modelled on the "feminist movement" failed, new campaigns appear to focus on "female strength", while discarding the "brand" of feminism.

PM planned to test market Virginia Slims Kings in Atlanta and New Orleans in October/November of 2000,5960 and Virginia Slims Kings was launched in late $2000 .{ }^{61}$ The launch plan included Bar Awareness Events, which were designed to generate awareness among young 21-29 year old smokers, and to generate names for a mailing list. ${ }^{62} \mathrm{~A}$ team of merchandisers were to visit 24 clubs and bars to get female adult smokers to complete a survey to enter a drawing to win tickets for a Macy Gray concert and a chance to be put on the VIP list. ${ }^{62}{ }^{63}$ The concert and bar promotions were carried out in Atlanta and New Orleans. ${ }^{64}$ The most recent Virginia Slims Kings document found was a PM retail creative brief from 27 March 2001 planning a buy one, get one free retail promotion in Atlanta and New Orleans in November 2001. ${ }^{65}$ There is no indication in the documents searched as to the final disposition of Virginia Slims Kings after the test markets.

\section{Difficulty appealing to both younger and older females}

Several promotional strategies were used during the 1990s in an effort to both maintain loyal, older Virginia Slims smokers and to try to acquire younger female competitive smokers. These campaigns included "Spa Days", the "Book of Days", "V-Wear", internet marketing, and direct mailings like the "Opinion Poll". ${ }^{66-70}$ The V-Wear promotion serves as an illustration of the difficulty PM had trying to market to both younger and older smokers.

Beginning around 1992 and continuing until at least 2001, the V-Wear campaign, which was a direct mailing catalogue with an assortment of branded items, included the use of direct mail, retail advertisements, print media, featured select items, and carton inserts. ${ }^{71}$ PM correspondence from 9 December 1992 between manager of premium brands, Shari Teitelbaum, and manager of promotions services for Virginia Slims, Barbara Trach, states the programme was very appealing to women in the sample: "These women liked the fact that this was a catalogue geared especially toward women-the female counterpart of Camel Cash."172-74 
However, a 1993 Marketing Perceptions study on V-Wear also found, "Some women rejected the items as 'too young-adult looking' (early 20's); 'too trendy' ('I don't follow the fads'); and, especially most of the clothing, 'too nightclubbish' ('I don't go out at night that much anymore' $)^{\prime \prime} .{ }^{75}$ A 7 September 1993 memo from Jeanne Bonhomme, Director of program development information marketing and sales for PM, to Clark Murray summarising this study stated that some respondents felt vintage clothing contradicted "You've Come a Long Way, Baby', the brand's unofficial slogan." ${ }^{176}$ In these 1993 promotions, it appears Virginia Slims struggled to market to their loyal, older franchise while simultaneously appealing to the young. Nonetheless, V-Wear promotions continued in 1994, 1997, and at least through 2001..$^{7178}$ The programme objectives continued to be to "leverage the Virginia Slims brand essence to reward and maintain longterm relationships with our franchise $. .{ }^{\prime \prime} .^{71}$

\section{DISCUSSION}

Prior studies have described the marketing activities targeting women using female oriented brand images, ${ }^{79} 80$ and how tobacco products have been targeted at females through extensive marketing in female oriented media (for example, Vogue magazine) both in the USA ${ }^{81-83}$ and in Europe. ${ }^{84-86}$ There is also evidence that these media outlets report very little about the health hazards of smoking. ${ }^{83}{ }^{87}$ Indeed, Ernster et al note the industry pays in excess of $\$ 5$ billion per year to market to women in the USA alone. ${ }^{80}$ Additionally, the introduction of cigarette brands targeted specifically to women in the late 1960s was associated with an enormous increase in female smoking. ${ }^{38}$ Nonetheless, prior studies on marketing to women primarily provide a synopsis of advertising activities and what the campaigns achieved; they often surmise the tobacco industry's intent from the advertising content. ${ }^{89}$

This paper provides one of the first analyses of marketing to women from the tobacco industry's point of view. Our study adds to a prior industry documents study describing marketing to working class women ${ }^{90}$ by discussing the evolution of female brands. As a signature female brand, Virginia Slims has been studied since its inception in $1968^{5689}$; the 2001 Surgeon General's Report on women and smoking describes Virginia Slims as "A case study in marketing success". ${ }^{3}$ This analysis shows that despite its success, Virginia Slims experienced a major crisis in the early 1990s that led to substantial internal research and efforts to remake the brand spanning at least 10 years.

The early 1990s decline in Virginia Slims market share among 18 to 24 year olds prompted extensive PM research to understand why the brand had lost relevance to young women and how it could regain its popularity. The extensive efforts to recruit young adult females, including launching the Virginia Slims Kings line extension, reinforce prior research showing that young adults are both essential to the tobacco industry, ${ }^{91}$ and vulnerable to these strategies. ${ }^{92}$ These efforts also coincide with the rise in young adult smoking rates observed in the late 1990s. ${ }^{93}{ }^{94}$ The Virginia Slims Kings bar nights described in this analysis echo tobacco industry young adult bar promotions detailed in prior studies. ${ }^{95-97}$

Our analysis of Virginia Slims also provides a detailed look at the aspirational images PM attempted to sell. One prior study using tobacco industry documents to illustrate targeting of women also found that the "product" being sold to women is self image. ${ }^{98}$ We found that the problem that PM faced in the 1990s was that Virginia Slims's brand "personality"-aspirational images of feminism, emotional independence, and social activism - was no longer relevant to young women. The strong brand image that served Virginia

\section{What this paper adds}

Prior research on tobacco marketing to women consists primarily of descriptive synopses of tobacco industry advertising, promotions, or sponsorship activities, where researchers must hypothesise about the tobacco industry's plans and intent for these efforts. This is one of the first papers which uses previously secret tobacco industry documents to provide a perspective on marketing to women from "inside" the industry by revealing tobacco marketers' research and development of female marketing campaigns with an internal analysis of their strengths and weaknesses.

Using Virginia Slims, the first and most successful brand marketed specifically to women, this paper shows that young adult women are critically important to sustaining the female market, and aspirational self images are the foundation of the brand image the industry sells to young women. Maintaining an image that is able to both retain aging established smokers and also attract new young smokers is an increasingly difficult task for the tobacco industry. Reaching young women is essential for tobacco marketers, and this is an untapped opportunity for public health efforts.

Slims well in the 1970s and 1980s became a liability in the 1990 s as the values of young women evolved. This image was also very difficult to change, as PM wanted to recruit younger female smokers while at the same time retaining its "loyal" older smokers. Although their efforts to recruit the youngest females may not have been entirely successful (as of June 2004 Virginia Slims Kings was not present in the market), PM has managed to update the look and feel of the Virginia Slims brand. In 2001, Virginia Slims advertising featured aspirational self affirming messages, such as "I am my own secret admirer" and continued its "loyalty building" promotions, such as the V-Wear catalogue. ${ }^{99}$

There are several potential limitations to this study. The large volume of tobacco industry documents and the inefficiency of their indexing make it difficult to be sure all relevant documents were found. We attempted to triangulate this data with outside sources, such as documenting the execution of advertising plans with published advertisements found in archives. This study focused on the evolution of a single brand; the tobacco industry may have pursued other strategies to market to women not included in this study. The qualitative studies discussed are subject to the limitations of those who conducted and reported the research, although it appears to meet industry standards of quality, and it was apparently the basis for multi-million dollar marketing decisions.

Most of the published literature that includes Virginia Slims still focuses on the slogan "You've come a long way, baby" and feminist imagery (for example, Richmond, $2003)^{100}$ even though this slogan and image lost relevance for the brand over a decade ago. Tobacco control research and counter-marketing efforts must address the newer images that have been developed to appeal to young women. For example, public outcry over the Virginia Slims 2000 "Find Your Voice" campaign, which featured exotic images of women of colour, resulted in the quick erosion of the positive imagery for the brand. ${ }^{101}$ A better understanding of tobacco industry strategies will ideally allow tobacco control efforts to anticipate the tobacco industry, rather than only reacting in response to its activities. ${ }^{102}$ Historically, PM was threatened by the view that the Virginia Slims image was outdated. As the prevalence of smoking begins to decrease among young women in the USA, ${ }^{103}$ there is a new opportunity for public 
health campaigns to frame tobacco brand images and smoking as outdated and increasingly unpopular.

Finally, note that Virginia Slims, while an emblematic female brand, is only $5.5 \%$ of the female cigarette market, much less than Marlboro, which has $38.6 \% .{ }^{104}$ Youth brands such as Marlboro and Newport have increasingly become the brands that recruit new young female smokers. Tobacco control programmes for young women should consider not only the exclusively female brands, but also the "unisex" brands and the associated mindsets and aspirations that are equally popular among young men and women.

\section{ACKNOWLEDGEMENTS}

This research was supported in part by the Office of Academic Affiliations, VA Special MIRECC Fellowship Program in Advanced Psychiatry and Psychology, Department of Veteran Affairs and by NIH grants K12-DA00167 and P50-DAl3334 and NCI grant CA87472. We would like to thank Dr Stanton Glantz for comments on earlier drafts of this paper.

\section{Authors' affiliations}

B A Toll*, Yale University School of Medicine, New Haven, Connecticut, USA

P M Ling, University of California, San Francisco, San Francisco, California, USA

*Also VA Connecticut Healthcare System, New Haven, Connecticut, USA

\section{REFERENCES}

1 Centers for Disease Control. Annual smoking-attributable mortality, years of potential life lost, and economic costs - United States, 1995-1999. MMWR Morb Mortal Wkly Rep 2002;51(14). http://www.cdc.gov/mmwr/ preview/mmwrhtml/mm5114a2.htm.

2 Shiffman S, Paton SM. Individual differences in smoking: gender and nicotine addiction. Nicotine Tob Res 1999;1(suppl 2):S153-7; discussion S165-6.

3 US Department of Health and Human Services. Women and smoking: a report of the Surgeon General - 2001. Washington DC: 2001, http://www.cdc.gov/tobacco/sgr_forwomen.htm.

4 Altria Group Inc. 2003 Annual Report: Altria Group Inc.; 2003. http:// www.altria.com/annualreport2003/ar2003_05_0100.asp (Accessed 8 June 2004).

5 Boyd TC, Boyd CJ, Greenlee TB. A means to an end: slim hopes and cigarette advertising. Health Promotion Practice 2003:4:266-277.

6 O'Keefe AM, Pollay RW. Deadly targeting of women in promoting cigarettes. J Am Med Women's Assoc 1996;51:67-9.

7 Malone RE, Balbach, eds. Tobacco industry documents: treasure trove or quagmire? [Comment in Tobacco Control 2000;9:261-2]. Tobacco Control 2000:9:334-8

8 Philip Morris. Virginia Slims Presentation. Dec 1967. Bates No. 1002916209/6224. http://legacy.library.ucsf.edu/tid/utg54e00 (Accessed 26 May 2004)

9 Gray EJ. Birth of Virginia Slims. 21 Apr 1969. Bates No. 1002430060/ 0062. http://legacy.library.ucsf.edu/tid/izq18e00 (Accessed 26 May 2004).

10 Martineau P. Papers From the 1969 A.A.A.A. Region Conventions How an Agency Builds a Brand - the Virginia Slims Story. 1970. Bates No. 1002430029/0059. http://legacy.library.ucsf.edu/tid/efc64e00 (Accessed 4 Jun 2004)

11 American Tobacco. A Consumer Survey Of Silva Thins And Virginia Slims Smokers. 1968. Bates No. 966060882/0890. http:// legacy.library.ucsf.edu/tid/epb70a00 (Accessed 26 May 2004).

12 Anon. Silva Thins, Filter And Menthol Research And Copy Presentation. 1968. (est.). Bates No. 990959387/9396. http://legacy.library.ucsf.edu/ $\mathrm{tid} / \mathrm{cih05f00} \mathrm{(Accessed} 16$ Aug 2004).

13 Philip Morris. Yes, Research Can Be Creative. 1986. Bates No. 2501040220/0267. http://legacy.library.ucsf.edu/tid/nqs19e00 (Accessed 26 May 2004).

14 Philip Morris International. Program Philip Morris International Marketing Seminar 680218-680227 Biltmore Hotel, New York City Williamsburg \& Richmond, Virginia. 18 Feb 1968. Bates No. 2500000234/0267. http:// legacy.library.ucsf.edu/tid/oej42e00 (Accessed 4 Jun 2004).

15 Faberman J. Virginia Slims Consumer Study. 19 Sep 1968. Bates No. 1002430065/0075. http://legacy.library.ucsf.edu/tid/ffc64e00 (Accessed 28 May 2004).

16 Faberman J. Evaluation of 'Project Clayton'. 12 Aug 1969. Bates No. 2010036750/6753. http://legacy.library.ucsf.edu/tid//pd98e00 (Accessed 26 May 2004).

17 Saleeby RNJ. Virginia Slims Performance in San Francisco. 17 Sep 1968. Bates No. 1002430063/0064. http://legacy.library.ucsf.edu/tid/ jzq18e00 (Accessed 28 May 2004).
18 Reynolds RJ. A Historical Perspective on Female Oriented Brands. 8 Jan 1981. Bates No. 503550723/0728. http://legacy.library.ucsf.edu/tid/ hay85d00 (Accessed 26 May 2004)

19 Leo Burnett Agency. Virginia Slims 1990 Marketing \& Advertising Program Recommendation. Aug 1989. Bates No. 2048683805/3920. http:// legacy.library.ucsf.edu/tid/kcv75e00 (Accessed 26 May 2004).

20 Philip Morris. 1979 Industry Review. 1979. Bates No. 2045377866/7869. http://legacy.library.ucsf.edu/tid/ity92e00 (Accessed 26 May 2004)

21 Pollay RW, Dewhirst T. The dark side of marketing seemingly "Light" cigarettes: successful images and failed fact. Tobacco Control 2002;11(suppl I):i18-31.

22 Ashley MJ, Cohen J, Ferrence R. 'Light' and 'mild' cigarettes: who smokes them? Are they being misled? Can J Public Health 2001;92:407-11.

23 Etter JF, Kozlowski LT, Perneger TV. What smokers believe about light and ultralight cigarettes. Prev Med 2003;36:92-8

24 Paul A. Warner Assoc. Summary Report of V.R.P. And Virginia Slims Superslims Creative Reaction. Dec 1989. Bates No. 513522798/2811 http://legacy.library.ucsf.edu/tid/dsw13d00 (Accessed 18 May 2004).

25 Bonhomme J. Marketing Research Department Report Superslims Ad Study. 14 May 1990. Bates No. 2071387987/8026. http:// legacy.library.ucsf.edu/tid/ins26c00 (Accessed 18 May 2004)

26 Leo Burnett Agency. Virginia Slims Agency Overview. 14 Jul 1994. Bates No. 2040144325/4395. http://legacy.library.ucsf.edu/tid/uyf75e00 (Accessed 28 May 2004)

27 Leo Burnett Agency. Virginia Slims Advertising Review. 17 Dec 1993. Bates No. 2048150275/0347. http://legacy.library.ucsf.edu/tid/rxml6e00 (Accessed 28 May 2004).

28 Geer, DuBois Inc. Brown \& Williamson Capri 1990 Recommended Media Plan Revised. 21 Sep 1989. Bates No. B00736239/6299. http:// legacy.library.ucsf.edu/tid/aycl 1 foO (Accessed 28 May 2004)

29 Brown and Williamson. Capri 960000 Brand Plan. No Date. Bates No. 432000421/0446. http://legacy.library.ucsf.edu/tid/mdq83f00 (Accessed 28 May 2004).

30 Kapuler Marketing Research Inc. Capri/Virginia Slims Creative Evaluation. Apr 1988. Bates No. $465663113 / 3174$. http://legacy.library.ucsf.edu/ tid/fhi90foo (Accessed 28 May 2004).

31 Alfano LL, American Tobacco. Misty Slims Focus Groups - Management Summary Report. 6 Feb 1990. Bates No. 970499999/970500002. hitp:// legacy.library.ucsf.edu/tid/fgl25f00 (Accessed 18 May 2004).

32 Schurtz J, Perception Research Services Inc. Summation of Misty Focus Groups. 27 Oct 1994. Bates No. 465849215/9224. http:// legacy.library.ucsf.edu/tid/zet90f00 (Accessed 28 May 2004)

33 Brown \& Williamson Tobacco Company. Our Company: B\&W History; 2004. http://www.brownandwilliamson.com/Index_sub2.cfm?ID = 10 . (Accessed June 4 2004).

34 Marketing Perceptions Inc. Exploring Attitudes, Lifestyles and Generational Statements of Young Adult Women a Qualitative Research Study. Mar 1991. Bates No. 2042942418/2448. http://legacy.library.ucsf.edu/tid/ dfn95e00 (Accessed 28 May 2004).

35 Marketing Perceptions Inc. Exploring Virginia Slims Imagery a Qualitative Research Summary. Aug 1993. Bates No. 2048965162/5180. http:// legacy.library.ucsf.edu/tid/maf36e00 (Accessed 28 May 2004).

36 Marketing Perceptions Inc. Exploring Virginia Slims Marketing Elements a Qualitative Research Summary. Feb 1994. Bates No. 2041774632/4646. http://legacy.library.ucsf.edu/tid/fbv62e00 (Accessed 28 May 2004).

37 Rodriguez Y. Virginia Slims Imagery and Elements Assessment Final Report. Exploring Virginia Slims Marketing Elements a Qualitative Research Summary. 4 Feb 1992. Bates No. 2041774683/4700. http:// legacy.library.ucsf.edu/tid/hye76e00 (Accessed 28 May 2004).

38 Bonhomme J. Virginia Slims Qualitative Imagery Research. 28 Sep 1993. Bates No. 2048960004/0006. http://legacy.library.ucsf.edu/tid/ dfv72e00 (Accessed 28 May 2004).

39 Murray C. Letter. 1 Mar 1994. Bates No. 2041734589. http:// legacy.library.ucsf.edu/tid/nwh76e00 (Accessed 30 May 2004)

40 Marketing Perceptions Inc. Exploring Response to Virginia Slims 'Quotes' a Qualitative Research Summary. Jan 1994. Bates No. 2040712466/2485. http://legacy.library.ucsf.edu/tid/ibg66e00 (Accessed 28 May 2004).

41 Rodriguez Y. Virginia Slims Outdoor Advertising Final Report. 19 Jan 1994. Bates No. 2041734438/4439. http://legacy.library.ucsf.edu/tid/ krs62e00 (Accessed 28 May 2004).

42 Marketing Perceptions Inc. An Exploration of Women's Issues a Qualitative Research Report. Nov 1994. Bates No. 2048964928/5007. http:// legacy.library.ucsf.edu/tid/ubu81f00 (Accessed 28 May 2004).

43 Philip Morris. Virginia Slims. It's a Woman Thing. 1995. Bates No. 2047174073. http://legacy.library.ucsf.edu/tid/ash35c00 (Accessed 28 May 2004).

44 Philip Morris. Virginia Slims. It's a Woman Thing. 1995. Bates No. 2047174072. http://legacy.library.ucsf.edu/tid/zrh35c00 (Accessed 28 May 2004).

45 Philip Morris. If We Liked Being Called 'Sweetie Pie,' We'd Change Our Names. Virginia Slims It's a Woman Thing. 1996. Bates No. 2041046622 http://legacy.library.ucsf.edu/tid/csw96e00 (Accessed 28 May 2004).

46 Philip Morris. Virginia Slims King Size Circumference Qualitative Research. May 1991. Bates No. 2076101058/1075. http://legacy.library.ucsf.edu/ $\mathrm{tid} / \mathrm{omb55c00}$ (Accessed 28 May 2004).

47 Henderson NR, Kensinger JL. Topline Report on Eight Focus Groups with Women Smokers About Issues Related to New Virginia Slims Kings. Dec 1991. Bates No. 2057763894/3911. http://legacy.library.ucsf.edu/tid/ $\mathrm{Hi} 09 \mathrm{e} 00$ (Accessed 28 May 2004)

48 Philip Morris. Marketing. Sep 1995. Bates No. 2048102974/2977. http:// legacy.library.ucsf.edu/tid/imol6e00 (Accessed 28 May 2004). 
49 Cohen C. Virginia Slims King Size Development. 31 Mar 1993. Bates No. 2057764108/4111. http://legacy.library.ucsf.edu/tid/ctj09e00 (Accessed 28 May 2004).

50 Philip Morris. Virginia Slims Kings Kickoff Meeting. 17 Nov 1995. Bates No. 2053845534/5571. http://legacy.library.ucsf.edu/tid/srq06c00 (Accessed 28 May 2004)

51 Rothman A. Creative Brief: Virginia Slims Kings 2000 Event. 15 Dec 1999. Bates No. 2081412958/2959. http://legacy.library.ucsf.edu/tid/ dfs81c00 (Accessed 28 May 2004)

52 Begley J. Virginia Slims Kings Retail Creative Brief. 17 Jan 2000. Bates No. 2081412928/2932. http://legacy.library.ucsf.edu/tid/sfs81 c00 (Accessed 28 May 2004)

53 Begley J. Virginia Slims Kings Advertising Creative Brief. 19 Jan 2000. Bates No. $2081412898 / 2899$. http://legacy.library.ucsf.edu/tid/dgs81c00 (Accessed 28 May 2004)

54 Philip Morris. Virginia Slims Kings Launch Date: 3rd Quarter, 1993. Jul 1993. Bates No. 2041814589/4596. http://legacy.library.ucsf.edu/tid/ jrd72e00 (Accessed 28 May 2004).

55 Rush S. Virginia Slims Kings Kickoff Meeting. 30 Oct 1995. Bates No. 2051036856/6857. http://legacy.library.ucsf.edu/tid/ehz47d00 (Accessed 28 May 2004).

56 Marketing Perceptions Inc. Exploring Response to Virginia Slims Kings Concepts a Qualitative Research Report. Mar 1996. Bates No. 2057909560/9582. http://legacy.library.ucsf.edu/tid/iic93c00 (Accessed 28 May 2004)

57 Marketing Perceptions Inc. Virginia Slims Kings a Qualitative Research Study Summary Findings. Jul 1998. Bates No. 2063516397/6408. http:// legacy.library.ucsf.edu/tid/gli05c00 (Accessed 28 May 2004).

58 Ellis N, Pitallano M. Virginia Slims Kings Qualitative Research. 23 Jul 1998 Bates No. 2063516395/6396. http://legacy.library.ucsf.edu/tid/dli05c00 (Accessed 28 May 2004)

59 Philip Morris. Virginia Slims Kings 1999-2000 Timeline. 30 Dec 1999. Bates No. 2081188030. http://legacy.library.ucsf.edu/tid/oid30c00 (Accessed 28 May 2004).

60 Philip Morris. Virginia Slims Kings 1999-2000 Timeline. 1999. Bates No. 2078724192/4193. http://legacy.library.ucsf.edu/tid/dnh91c00 (Accessed 28 May 2004).

61 Butler R. Virginia Slims Kings Direct Mail Creative Brief (4/01-12/01). 8 Nov 2000. Bates No. 2081223053/3055. http:// legacy.library.ucsf.edu/tid/wcg30c00 (Accessed 28 May 2004).

62 Philip Morris. Virginia Slims Kings Test Market Introductory Event. 31 May 2000. Bates No. 2081222886/2893. http://legacy.library.ucsf.edu/tid/ qsf30c00 (Accessed 28 May 2004).

63 Philip Morris. Virginia Slims Kings "Her Majesty's Jam" Week of October 6th. 13 Oct 2000. Bates No. 2081222727/2728. http:// legacy.library.ucsf.edu/tid/wvf30c00 (Accessed 28 May 2004)

64 Gary M. Reynolds \& Associates Inc. Her Majesty's Jam Virginia Slims Kings. 19 Dec 2000. Bates No. 2081222854/2879. http:// legacy.library.ucsf.edu/tid/ysf30c00 (Accessed 28 May 2004).

65 Simmons S. Virginia Slims Kings 2001 Retail Creative Brief. 27 Mar 2001 Bates No. 2081412883/2884. http://legacy.library.ucsf.edu/tid/ igs81c00 (Accessed 28 May 2004).

66 Philip Morris. Virginia Slims "Refresh \& Renew Day" Overview. 30 Apr 1999. Bates No. 2080703047/3059. http://legacy.library.ucsf.edu/tid/ lew91c00 (Accessed 28 May 2004)

67 Leo Burnett Agency. 1990 Pm Direct Mail Statistics. 10 Dec 1999. Bates No. 2080329628/9639. http://legacy.library.ucsf.edu/tid/fmu38c00 (Accessed 28 May 2004)

68 Philip Morris. Virginia Slims Opinion Poll Documents 30 Years of Change for Women. 14 Apr 2000. Bates No. 2072937512/7515. http:// legacy.library.ucsf.edu/tid/zhu27d00 (Accessed 28 May 2004).

69 Butler R. Creative Brief: 2002 Book of Days Calendar Refill Inserts. 14 Dec 2000. Bates No. 2081412895/2897. http://legacy.library.ucsf.edu/tid/ egs81c00 (Accessed 28 May 2004)

70 Sonville M. Internet Exploratory and Development Creative Brief. $10 \mathrm{Apr}$ 2001. Bates No. 2080310357/0363. http://legacy.library.ucsf.edu/tid/ oqs38c00 (Accessed 28 May 2004).

71 Rothman A. Creative Brief: 3Q2001 V-Wear Continuity. 2 Aug 2000. Bates No. 2081412892/2894. http://legacy.library.ucsf.edu/tid/fgs81c00 (Accessed 28 May 2004)

72 Teitelbaum S. V Wear Focus Groups Final Report. 9 Dec 1992. Bates No. 2047256290/6291. http://legacy.library.ucsf.edu/tid/dat17e00 (Accessed 28 May 2004)

73 Philip Morris. Program Development, Marketing \& Sales Information \& Analysis. 1995. Bates No. 2048102979/2998. http:// legacy.library.ucsf.edu/tid/olol 6e00 (Accessed 30 May 2004)

74 Trach B. Letter. 30 Dec 1994. Bates No. 2046825159. http:// legacy.library.ucsf.edu/tid/olk24c00 (Accessed 30 May 2004)

75 Marketing Perceptions Inc. Exploring Response to Spring 1994 V Wear a Qualitative Research Summary. Aug 1993. Bates No. 2040752325/2337. http://legacy.library.ucsf.edu/tid/kpt62e00 (Accessed 28 May 2004).

76 Bonhomme J, Marrullier A. Virginia Slims V Wear Research. 7 Sep 1993. Bates No. 2048960038/0040. http://legacy.library.ucsf.edu/tid/ dse36e00 (Accessed 28 May 2004).

77 Philip Morris. Review of Virginia Slims V Wear Promotion. 18 May 1994. Bates No. 2040419073/9086. http://legacy.library.ucsf.edu/tid/ elh76e00 (Accessed 28 May 2004).
78 Philip Morris. 1997 Fall V Wear Program Overview. 20 Dec 1996. Bates No. 2080958261/8267. http://legacy.library.ucsf.edu/tid/ayb18c00 (Accessed 28 May 2004).

79 Amos A. Women and smoking. Br Med Bull 1996:52:74-89.

80 Ernster V, Kaufman N, Nichter $M$, et al. Women and tobacco: moving from policy to action. Bull WHO 2000;78:891-901.

81 Albright CL, Altman DG, Slater MD, Maccoby N. Cigarette advertisements in magazines: evidence for a differential focus on women's and youth magazines. Health Education Quarterly 1988;15:225-33.

82 Feit MN. Exposure of adolescent girls to cigar images in women's magazines, 1992-1998. Am J Public Health 2001;91:286-88.

83 Hoffman-Goetz L, Gerlach KK, Marino C, et al. Cancer coverage and tobacco advertising in African American women's popular magazines. $J$ Community Health 1997;22:261-70.

84 Amos A, Jacobson B, White P. Cigarette advertising policy and coverage of smoking and health in British women's magazines. Lancet 1991;337:93-6.

85 Amos A, Bostock Y. Policy on cigarette advertising and coverage of smoking and health in European women's magazines. BMJ 1992;304:99-101.

86 Amos A, Bostock C, Bostock Y. Women's magazines and tobacco in Europe. Lancet 1998;352:786-7

87 Warner KE, Goldenhar LM, McLaughlin CG. Cigarette advertising and magazine coverage of the hazards of smoking: a statistical analysis. N Engl J Med 1992;326:305-9.

88 Pierce JP, Lee L, Gilpin EA. Smoking initiation by adolescent girls, 1944 through 1988: An association with targeted advertising. JAMA 1994;271:608-11

89 Amos A, Haglund M. From social taboo to "torch of freedom": the marketing of cigarettes to women. Tobacco Control 2000;9:3-8.

90 Barbeau EM, Leavy-Sperounis A, Balbach ED. Smoking, social class, and gender: what can public health learn from the tobacco industry about disparities in smoking? Tobacco Control 2004;13:115-20.

91 Ling PM, Glantz SA. Why and how the tobacco industry sells cigarettes to young adults: evidence from industry documents. Am J Public Health 2002;92:908-16.

92 Biener $L$, Albers $A B$. Young adults: vulnerable new targets of tobacco marketing. Am J Public Health 2004;94:326-30.

93 Lantz PM. Smoking on the rise among young adults: Implications for research and policy. Paper presented at the Innovations in Youth Tobacco Control Conference, 2002.

94 Wechsler H, Rigotti NA, Gledhill-Hoyt J, et al. Increased levels of cigarette use among college students: a cause for national concern [published erratum appears in JAMA 1999;281:136]. JAMA 1998;280:1673-8.

95 Sepe E, Glantz SA. Bar and club tobacco promotions in the alternative press: targeting young adults. Am J Public Health 2002;92:75-8.

96 Sepe E, Ling PM, Glantz SA. Smooth moves: bar and nightclub tobacco promotions that target young adults. Am J Public Health 2002:92:414-9.

97 Katz SK, Lavack AM. Tobacco related bar promotions: insights from tobacco industry documents. Tobacco Control 2002;1 1(suppl I):i92-101.

98 Deland K, Lewis K, Taylor AL. Developing a public policy response to the tobacco industry's targeting of women and girls: the role of the WHO Framework Convention on Tobacco Control. J Am Med Women's Assoc 2000;55:316-19.

99 Anon. Trinkets and Trash. Trinkets and Trash: Artifacts of the tobacco epidemic, University of Medicine and Dentistry New Jersey; 200415 May 2004. http://www.trinketsandtrash.org/ (Accessed 29 May 2004).

100 Richmond R. You've come a long way baby: women and the tobacco epidemic. Addiction 2003;98:553-7.

101 Fairclough G. Philip Morris Removes Slogan From Ads In Second Attempt Responding to Critics. Wall Street Journal, 200013 June;Sect.6 Col 1.

102 Ling PM, Glantz SA. Using tobacco-industry marketing research to design more effective tobacco-control campaigns. JAMA 2002;287:2983-9.

103 National Center for Health Statistics. Health, United States, 2003 With Chartbook on Trends in the Health of Americans. Hyattsville, Maryland: National Center for Health Statistics, 2003, http://www.cdc.gov/nchs/ hus.htm.

104 Substance Abuse and Mental Health Services Administation. 2002 National Survey on Drug Use \& Health. Washington DC: Substance Abuse and Mental Health Services Administation, 2004, http:// www.oas.samhsa.gov/nhsda.htm\#NHSDAinfo.

105 Philip Morris. Philip Morris USA Market Share Information 1974-1996. 1996. Bates No. 2077996067/6095. http://legacy.library.ucsf.edu/tid/ ahy75c00 (Accessed 8 Jun 2004).

106 Holbert N. Virginia Slims Attitude Study. 4 Dec 1973. Bates No. 1000735990/6007. http://legacy.library.ucsf.edu/tid/awb28e00 (Accessed 8 Jun 2004).

107 Philip Morris. Virginia Slims 2000 Plan. 22 Sep 1999. Bates No. $2081223001 / 3047$. http://legacy.library.ucsf.edu/tid/adg30c00 (Accessed 8 Jun 2004).

108 Philip Morris Inc. 2001 Business Review; 2001. http://www.altria.com/ investors/annual_report/bus_review/bus_review01.asp (Accessed 8 June 2004).

109 Altria Group Inc. 2002 Annual Report: Altria Group Inc.; 2002. http:// www.altria.com/annualreport2002/ar2002_05_0100.asp (Accessed 8 June 2004). 